\title{
Analysis of Fire Catchers in Sago Palm Smallholding Plantations on Peatland in Tebing Tinggi Timur, Kepulauan Meranti District, Riau Province
}

\section{(Analisis Penangkap Kebakaran di Perkebunan Kelapa Sawit Sagu di Lahan Gambutdi Tebing Tinggi Timur, Kabupaten Kepulauan Meranti, Provinsi Riau)}

\author{
Sinta Haryati Silviana ${ }^{1 \star}$, Ahmad Muhammad ${ }^{1}$, Haris Gunawan², Imam Basuki ${ }^{2}$ \\ (Received November 2019/Accepted Februari 2021)
}

\begin{abstract}
Fire on peatlands takes place not only in areas where preparation for cultivation is in progress, but also in areas that have been cultivated, such as for sago palm growing. One of the important factors that influence the vulnerability of cultivated peatlands to fire is the availability and amount of biomass fuel that easily catches fire, such as ferns, grasses, and broadleaved shrubs in their living as well as dead (litter) stages. The present study concerns the vulnerability of peatland utilized for sago growing by smallholders, focused in Tebing Tinggi Timur, Kepulauan Meranti District, Riau Province. The objectives of this study were to analyze the composition and assess the biomass of fire catchers in the sago palm plantation. Data collection was conducted in three locations in Kepau Baru Village. In each location, a $1000 \mathrm{~m}$-long transect line was drawn and 10 sampling plots of $2 \mathrm{~m} \mathrm{x} 2 \mathrm{~m}$ were established along the line with $100 \mathrm{~m}$ intervals. Results showed that total biomass of fire catchers in this growing system was averaged at $24681 \mathrm{~kg} / \mathrm{ha}$, in which the dead plant fraction was predominating (average at $17478 \mathrm{~kg} / \mathrm{ha}$ or $70.81 \%$ ) over the living plant fraction (in average $7203 \mathrm{~kg} / \mathrm{ha}$ or $29.19 \%)$. The latter consisted of ferns that averaged at $2.191 \mathrm{~kg} / \mathrm{ha}$ or $30.42 \%$, grasses $(20 \mathrm{~kg} / \mathrm{ha}$ or $0.28 \%)$, nonwoody broadleaved shrubs $(581 \mathrm{~kg} / \mathrm{ha}$ or $8.07 \%)$, and woody broadleaved shrubs $(4411 \mathrm{~kg} / \mathrm{ha}$ or $61.24 \%)$. The amount of fire catchers in relatively large quantities in this plantation system could magnify fire risk during drier months, especially during El-nino years.
\end{abstract}

Keywords: biomass, fire risk, grasses, non-woody broadleaved shrubs, woody broadleaved shrubs

\section{ABSTRAK}

Kebakaran di lahan gambut terjadi tidak hanya di daerah di mana persiapan untuk budi daya sedang berlangsung, tetapi juga di daerah yang telah dibudidayakan, seperti untuk penanaman kelapa sawit. Salah satu faktor penting yang memengaruhi kerentanan lahan gambut yang dibudidayakan untuk terbakar adalah ketersediaan dan jumlah bahan bakar biomassa yang mudah terbakar, seperti pakis, rumput, dan semak berdaun lebar dalam kehidupan mereka serta tahapan mati (serasah). Studi saat ini berkaitan dengan kerentanan lahan gambut yang digunakan untuk penanaman sagu oleh petani kecil, yang difokuskan di Tebing Tinggi Timur, Kabupaten Kepulauan Meranti, Provinsi Riau. Tujuan penelitian ini adalah untuk menganalisis komposisi dan menilai biomassa penangkap api di perkebunan sagu. Pengumpulan data dilakukan di tiga lokasi di Desa Kepau Baru. Di setiap lokasi, ditarik garis transek sepanjang $1000 \mathrm{~m}$ dan 10 plot pengambilan sampel berukuran $2 \mathrm{~m} \times \mathbf{2} \mathrm{m}$ dibuat sepanjang garis dengan interval $100 \mathrm{~m}$. Hasil menunjukkan bahwa total biomassa penangkap api dalam sistem pertumbuhan ini rata-rata $24.681 \mathrm{~kg} / \mathrm{ha}$, di mana fraksi tanaman mati mendominasi (rata-rata $17.478 \mathrm{~kg} / \mathrm{ha}$ atau $70,81 \%$ ) di atas fraksi tanaman hidup (rata-rata $7.203 \mathrm{~kg} / \mathrm{ha}$ atau $29,19 \%)$. Yang terakhir terdiri atas pakis yang rata-rata $2,191 \mathrm{~kg} / \mathrm{ha}$ atau $30,42 \%$, rumput $(20 \mathrm{~kg} / \mathrm{ha}$ atau $0,28 \%)$, semak berdaun lebar non-kayu $(581 \mathrm{~kg} / \mathrm{ha}$ atau $8,07 \%)$, dan semak berdaun lebar berkayu $(4.411 \mathrm{~kg} / \mathrm{ha}$ atau $61,24 \%$ ). Jumlah pemadam kebakaran dalam jumlah yang relatif besar dalam sistem perkebunan ini dapat memperbesar risiko kebakaran selama bulan-bulan kering, terutama selama tahun-tahun El-nino.

Kata kunci: biomassa, risiko kebakaran, rumput, semak berdaun lebar non-kayu, semak berdaun lebar kayu

\footnotetext{
1 Department of Biology, Faculty of Mathematics and Natural Sciences, Riau University, Jl. HR Soebrantas Km 12,5 Kelurahan Simpang Baru, Kecamatan Tampan, Pekanbaru, Riau 28293

2 PT. Winrock International, B Jl. Ampera Raya 11 Jakarta 12550

* Coresspondence Author:

Email:sintaharyatis@gmail.com
}

\section{INTRODUCTION}

Peatlands are water-saturated land that provides various ecosystem services and biodiversity (Rieley et al. 2008). Riau Province composed by peatland area at around 4.04 million hectares, or $56.1 \%$ of the peatlands total area in Sumatra Island (Murdiyarso 
et al. 2004). Land and forest fires are serious problems in Indonesia, which had become an international concern. The use of fire in land preparation is believed as the main cause of those fires, especially on peatlands which had been drained as a result of overly massive drainage canal system (Harrison et al. 2009). In the last 15 years, the fires have increasingly been common on peatlands. Considering the huge amount of carbon stored in peatlands, fires can cause a significant amount of carbon released into the atmosphere. This condition can disrupt the global climate balance (Hooijer et al. 2006). Riau Province is one of the regions in Indonesia where peat fires occur quite often. This condition not only happens in areas that are being opened for cultivation, but also in cultivated areas, including those used for sago palm plantations. In 2014, for example, there was a largescale fire in sago palm plantation areas in Meranti Islands Regency, Tebing Tinggi Timur District.

As widely reported, fire events have always been triggered by humans, both intentionally and accidentally. Even so, many other factors actually affect the level of fire vulnerability of peatlands, such as the availability of fuel in the form of fire-capture biomass plants, namely "highly flammable" plants (Wagner 1987). Plant biomass is one of the three components needed in the process of $f$ ire, in addition to heat sources and oxygen, called the fire triangle (Brown and Davis 1973). Forest fuel is a variety of organic materials (plants) that are alive or dead and can be burned when there is a source of fire (Chandler et al. 1983). In this case, the water content in the plant will determine its flammability. The lower the water content in the plant, the more flammable it will be, and vice versa (Saura et al. 2010). The available fuel characteristics will affect the behavior of the fire, including the fuel size, arrangement, volume, type, density, and moisture content of the fuel (Clar CR and LR Chatten 1954). In addition, the fuel load or the amount of fuel available within an area, expressed in $\mathrm{kgs} / \mathrm{ha}$, will also affect the fire-propagation factor during fires.

District of Tebing Tinggi Timur, Kab. Kep Meranti, Riau Province, known to have two sago cropping systems, namely small-scale plantations or sago palm smallholding plantations and largescale plantations or industrial plantations. The management styles between the two cropping systems thought to have an influence on the characteristics and the existence of fire capture biomass. In small-scale plantations or traditional system, the sago plant is managed extensively and is a poly-specific system (Haryanto \& Pangloli 1992), while in plantations it is managed intensively and is a monospecific system (Bintoro et al. 2010). Without proper maintenance, forests or sago plantations are very flammable that may facilitate fires to take dry litter or understory. This research concerned about $f$ ire-catching plants in sago plantations within the peatland area in Tebing Tinggi Timur District. The purpose of this study was to analyze the biomass composition and estimates of fire-catching plants in this sago plantation system. This paper presents the results obtained and discussed in relation to fire vulnerability in this system.

\section{MATERIAL AND METHODS}

\section{Place and time of research}

This research was carried out in Kepau Baru Village, Tebing Tinggi Timur District, Meranti Island Regency, Riau Province, in the period between December 2015 until March 2016. In this case, three small-scale plantations or traditional system were randomly selected in separate locations.

\section{Collect Data}

At each location, an observation was carried out with the help of a $1000 \mathrm{~m}$ long transect line that split the small-scale plantations. On this transect, 10 plots of $2 \mathrm{~m} \times 2 \mathrm{~m}$ were made with intervals of 100 $\mathrm{m}$. Observation of fire-capture plant biomass by observing burnt sago groves, it was clear that the sago plants themselves are generally not burned. Plant biomasses that are almost always burnt are of ferns, grasses, non-woody broadleaved shrubs, and woody broadleaved shrubs. In addition, burnt plant biomasses are in the form of litter (dead plants) as well as dry sago midribs. These biomasses were the fire-capture plants that became the focus of this research. All plants in the sampling plot were cut just above the soil surface. Plant samples were grouped according to their shapes, such as ferns, grasses, non-woody broadleaved shrubs, woody broadleaved shrubs, as well as dead-plant biomass and weighed. Plant samples were weighed and recorded as wet weights (BB). Plant biomass obtained in each plot was expressed as dry weight (BK) after drying was carried out at $1,100^{\circ} \mathrm{C}$ for 48 hours in an oven. BK calculation was done using the modified formula from (Brown 1997) as below and based on weighing $200 \mathrm{~g}$ of dried samples.

$$
B K=B B / 200 \times B S
$$

\section{Evenness observation and understorey thickness}

Understorey-plant cover-abundance and sociability were measured and noted from every plot in the transect lines, using Braun and Blanquet method. Plot condition was captured using a digital camera from its four corners. The final score of the plot would be a sum value of plant cover and density. A final score of transect was the average value of the 10 plots (Table 1 ).

\section{Data analysis}

Descriptive analysis in the form of calculating the 
average value of biomass fractions of fire-catching plants was carried out using Microsoft Excel.

\section{RESULTS AND DISCUSSION}

\section{The Mass of Fuel}

The results of the research (Table 2) showed that the availability of fuel (biomass; fire-capture plants) in sago plantations of the community in Kepau Baru Village reached an average of $24681 \mathrm{~kg} / \mathrm{ha}$. In this case, it turns out that the biomass fraction in the form of living plants averages only $7203 \mathrm{~kg} / \mathrm{ha}$ (29.19\%). The biomass fraction in the form of dead plants (necro mass) is much larger than those of biomass, namely $17478 \mathrm{~kg}$ ha $(70.81 \%)$. In terms of composition, the most dominant living plants are ferns, with the average biomass reaches 2,191 $\mathrm{kg} / \mathrm{ha}(30.41 \%)$. The smallest fraction is in the form of grass, which is on average only $20 \mathrm{~kg} / \mathrm{ha}$ $(0.27 \%)$.

The amount of biomass fraction in the form of dead plants is probably related to these two following conditions. First, fire-capture plants, in this case, those in the form of ferns and grasses, are generally relatively short-lived plant species (Wilson 1985), so that their biomasses do not accumulate as living tissue. Second, after the plants die and become litter, the decomposition process may require a relatively long time, especially in the form of woody shrubs (Mason 1977). This causes the accumulation of biomass-catching plants. The large fraction of ferns biomass might be related to the density of shading in the community sagocropping system due to the high density of plants. In adjacent locations revealed the density of sago groves in smallholder's Sago-Palm plantations (Pittameka et al. 2016). Shelter density can play a role as a selected group and plant species that can be co-exist alongside and around the sag o plant. In this case, ferns were dominated by Nephrolepis biserrata which seems to be more tolerant of shade than other types of ferns, such as Dicranopteris linearis and Spatochlaena palustris. It was also more dominant than those types of grass, especially Imperata cylindrica. The results of this study indicate that in sago groves there are approximately $1.75 \mathrm{~kg} / \mathrm{m}^{2}$ biomass of fire-catching plants in the form of dead plants and $0.72 \mathrm{~kg} / \mathrm{m}^{2}$ in the form of live plants. In reality, the cursory biomass is not how large it can have a large enough volume, with a height of between $0.20-2.0 \mathrm{~m}$ above ground level. The results of this study indicate that in sago groves there are approximately $1.75 \mathrm{~kg} \mathrm{~m}^{2}$ biomass of firecatching plants in the form of dead plants and about $0.72 \mathrm{~kg} / \mathrm{m}^{2}$ in the form of living plants. In reality, the biomass is not large in volume, with a height of between $0.20-2.0 \mathrm{~m}$. In the dry season, these two biomasses fractions are easily losing water content, making it more flammable (Baeza et al. 2002). This is quite alarming when considering the habit of working while smoking is quite widespread among workers in Sago Palm Smallholding Plantations.

\section{Measurement of Understorey-Plant Cover- Abundance and Sociability}

The vegetation structure of land cover type can be seen from the level of evenness and intensity. In this case, evenness shows the proportion of the land surface covered by plants, while the density is the number of plants within the land. The results of this study reveal that the level of evenness of land cover vegetation in Sago Palm Plantations is generally "very even" (with scores ranging from 4-5 or with $60-80 \%$ cover). But evenness of the lower vegetation does not necessarily indicate the level of sociability. The level of sociability in Sago Palm Plantations is "thick" (with a score of 4).

Table 1 Reference for scoring on understorey plant abundance and density

\begin{tabular}{cll}
\hline Score & Cover-abundance percentage of plants & Sociability of plants \\
\hline 1 & None/very low $(<20 \%)$ & None/very low \\
2 & Low $(20-40 \%)$ & Low \\
3 & Moderate $(>40-60 \%)$ & Moderate \\
4 & High $(>60-80 \%)$ & Dense \\
5 & Very high $(>80 \%)$ & Very dense \\
\hline
\end{tabular}

Table 2 Mass of fuel in sago plantations in the field

\begin{tabular}{lr}
\hline \multicolumn{1}{c}{ Parameter } & Average of biomass (kg/ha) \\
\hline Total fuel mass & 24681 \\
The total-plant fraction lives & 7203 \\
Living-plant fractions in the form of ferns & 2191 \\
Living-plant fractions in the form of grasses & 20 \\
The living-plant fraction is a non-woody broadleaved shrub & 581 \\
The living-plant fraction consists of woody broadleaved shrubs & 4411 \\
Dead plant biomass fraction & 17478 \\
\hline
\end{tabular}




\section{CONCLUSION}

Based on the research results, it can be concluded that the fire-catching fuel contained in Sago Palm Plantations on peatland reaches an average of $24,681 \mathrm{~kg} / \mathrm{ha}$. This fuel is dominated by fractions in the form of dead plant biomass, which was $17,478 \mathrm{~kg} / \mathrm{ha}(70.81 \%)$, and the fraction of live plants were on average only $7,203 \mathrm{~kg} / \mathrm{ha}(29.19 \%)$. Living plant fractions in the form of fern was 2,191 $\mathrm{kg} / \mathrm{ha}(30.42 \%)$, grass $20 \mathrm{~kg} / \mathrm{ha}(0.28 \%)$, woody broadleaf bushes $581 \mathrm{~kg} / \mathrm{ha}(8.07 \%)$ and in the form of woody broadleaf bushes $4411 \mathrm{~kg} / \mathrm{ha}(61.24 \%)$. The availability of relatively large fire capture fuels have the potential to increase the risk of fire, especially in the dry season

\section{ACKNOWLEDGEMENTS}

The author would like to thank PT. Sampoerna Agro for the assistance provided for this study. The awards were presented to Mr. Albertus Fajar, Mr. Harry Susanto, Mr. Bambang Erawan, Ms. Yusi Rosalina, Mr. Mika Asri Selian, Mr. Mochammad Suwarno, Mr. Nierza Alfiannur, and Mr. Maruli for facilitation during research in the field.

\section{REFERENCES}

Baeza M J, Lui M D, Raventos J, Escarre A. 2002. Factors Inf luencing Fire Behaviour in Shrublands of Different Stand Ages and the Implications for Using Prescribed Burning to Reduce Wildfire Risk. Journal Environment Management. 65(2): 199-208. https://doi.org/10.1006/jema.2002.0545

Bintoro MH, Purwanto, Amarilis S. 2010. Sagu di Lahan Gambut. Bogor (ID): Institut Pertanian Bogor Press.

Brown S. 1997. Estimating Biomass and Biomass Change of Tropical Forest-A Primer. FAO Forestry Paper 134. Urbana (EN): FAO.

Brown, Davis. 1973. Forest Fire Control and Use. New York (US): McGraw-Hill.

Chandler CP, Cheney P, Thomas L, Trabaud, Williams D. 1983. Fire in Forestry: Forest Fire Behavior and Effects. Vol 1. NewYork (US): Jhon Willey and Sons, Inc.
Clar CR, LR Chatten. 1954. Principles of Forest Fire Management. New York (US): Mc. Graw Hill Book Company.

Harrison ME, Page SE, Limin SH. 2009. The Global Impact of Indonesia Forest $f$ ire. Journal of Biological Education 56(3): 156-163.

Haryanto B, Pangloli P. 1992. Potensi dan Pemamfaatan Sagu. Yogyakarta (ID): Penerbit Konisius.

Hooijer A, Silvius M, Wösten H, Page S. 2006. PEAT-CO ${ }^{2}$. Assessment of $\mathrm{CO}^{2}$ emissions from drained peatlands in SE Asia.

Mason CF. 1977. Decomposition. The Institute of Biology. Studies in Biology No. 74. London (ID): Edward Arnold.

Murdiyarso D, Rosalina U, Hairiah K. Muslihat L. Suryadiputra INN, Jaya A. 2004. Petunjuk Lapangan: Pendugaan Cadangan Karbon pada Lahan Gambut. Proyek Climate Change. Forest and Peatlands in Indonesia. Wetlands International - Indonesia Program dan Wildlife Habitat Canada. Bogor Indonesia. Bogor (ID).

Pittameka AL, Muhammad A, Gunawan H, Irawan A F 2016 Analisis Struktur Tegakan Sagu (Metroxylon Sagu Rottb.) dalam Dua Sistem Pertanaman pada Lahan Gambut [skripsi]. Pekanbaru (ID): Universitas Riau.

Rieley JO, Wüst RAJ, Jauhiainen J, Page SE, Wösten H, Hoijer A, Siegert F, Limin S, Vasander $\mathrm{H}$, Stahlhut 2008. Tropical peatlands: carbon store. carbon gas emissions and contribution to climate change processes. International Peat Society. p 148-181

Saura Mas S, S Paula, JG Pauses, Lloret F. 2010. Fuel Loading and Flammability in the Mediterranean Basin Woody Species with Different Post-Fire Regenerative Strategies. International Journal of Wildland Fire 19: 783-794. https://doi.org/10.1071/WF09066

Wagner VCE. 1987. Develompment and Structure of the Canadian. Forest Fire Weather Index. Journal of Forest Research. 35(7): 23-34.

Wilson RJ. 1985. Observations of Extinction and Marginal Burning States in Free-Burning Porous Fuelbeds. Combustion Science and Technology 44 (4): 179-193. https://doi.org/10.1080/ 00102208508960302 